\title{
Clinical update on linezolid in the treatment of Gram-positive bacterial infections
}

This article was published in the following Dove Press journal:

Infection and Drug Resistance

18 June 2012

Number of times this article has been viewed

\author{
Sally Ager \\ Kate Gould \\ Department of Microbiology, \\ Newcastle upon Tyne Hospitals Trust, \\ Freeman Hospital, High Heaton, \\ Newcastle upon Tyne, UK
}

\begin{abstract}
Gram-positive pathogens are a significant cause of morbidity and mortality in both community and health care settings. Glycopeptides have traditionally been the antibiotics of choice for multiresistant Gram-positive pathogens but there are problems with their use, including the emergence of glycopeptide-resistant strains, tissue penetration, and achieving and monitoring adequate serum levels. Newer antibiotics such as linezolid, a synthetic oxazolidinone, are available for the treatment of resistant Gram-positive bacteria. Linezolid is active against a wide range of Gram-positive bacteria and has been generally available for the treatment of Gram-positive infections since 2000. There are potential problems with linezolid use, including its bacteriostatic action and the relatively high incidence of reported adverse effects, particularly with long-term use. Long-term use may also be complicated by the development of resistance. However, linezolid has been shown to be clinically useful in the treatment of several serious infections where traditionally bacteriocidal agents have been required and many of its adverse effects are reversible on cessation. It has also been shown to be a cost-effective treatment option in several studies, with its high oral bioavailability allowing an early change from intravenous to oral formulations with consequent earlier patient discharge and lower inpatient costs.
\end{abstract}

Keywords: linezolid, oxazolidinone, multi-resistant, gram-positive, MRSA, VRE, cost-benefit

\section{Introduction to the management of Gram-positive bacterial infections}

Gram-positive pathogens, including Staphylococcus aureus, enterococci, and Streptococcus pneumoniae, cause significant morbidity and mortality in the community and hospital settings. Infections due to multidrug-resistant Gram-positive bacteria are increasing in prevalence, with an increase in the incidence of virulent clones of community-acquired methicillin-resistant $S$. aureus (MRSA), multidrug-resistant S. pneumoniae, and enterococci species which are increasingly resistant to multiple antimicrobial agents in many parts of the world. The traditional antibiotic of choice for these multiresistant pathogens has been vancomycin but there is an increase in treatment failure as vancomycin-resistant strains have emerged. Glycopeptide treatment also has inherent problems with drug penetration into tissues and the need to monitor and achieve adequate serum levels. Newer antibiotics available for use against resistant Gram-positive bacteria include linezolid, daptomycin, quinupristin/dalfopristin, tigecycline, and semisynthetic lipoglycopeptides, such as telavancin. Cephalosporins and carbapenems with MRSA activity are also being developed.

Linezolid was the first oxazolidinone developed. It was approved for clinical use in the US in April 2000 and in the UK in January 2001. Its licensed indications include
Correspondence: Sally Ager Department of Microbiology, Newcastle upon Tyne Hospitals Trust, Freeman Hospital, High Heaton, Newcastle upon Tyne, NE7 7DN, UK Tel +44 019l 213/248 Email sally.ager@nuth.nhs.uk 
community-acquired and nosocomial pneumonia and skin and soft tissue infections. It is licensed for pediatric use in the US but not in the UK.

\section{Microbiological activity}

Linezolid is active against a wide-range of Gram-positive aerobic bacteria ${ }^{1}$ and some Gram-positive anaerobes, including Actinomyces spp. It is also active against some Gram-negative anaerobic bacteria, several Mycobacterial species and against Nocardia spp.

\section{Gram-positive aerobic bacteria}

Linezolid has good activity against many Gram-positive aerobic bacteria, including resistant strains of several species, such as MRSA, penicillin-resistant pneumococci (PRP), and vancomycin-resistant enterococci (VRE).

Minimum inhibitory concentrations (MICs) of coagulase-negative staphylococci (CoNS) are generally lower to linezolid than those of $S$. aureus spp. ${ }^{2}$ MICs to linezolid of both CoNS and $S$. aureus are not altered by whether the strains are methicillin-susceptible or resistant: ${ }^{3}$ decreased susceptibility of staphylococcal species to vancomycin is not associated with decreased susceptibility to linezolid. ${ }^{4}$

Linezolid is active against many streptococci, including group A, B, C, F, and G $\beta$-hemolytic streptococci, viridians streptococci, and entrococci. ${ }^{5-7}$ Most streptococci have MICs ranging up to $2 \mathrm{mcg} / \mathrm{mL}$, although some group A streptococci and some strains of viridians streptococci have been found to have MICs up to $4 \mathrm{mcg} / \mathrm{mL}^{8}{ }^{8}$ PRP remain susceptible to linezolid. ${ }^{9}$ Vancomycin-susceptible enterococci and VRE have similar MICs to linezolid. ${ }^{2,3}$ Corynebacterium spp., Listeria monocytogenes, Bacillus spp., Rhodococcus equi, Nocardia spp., and many Lactobacillus spp. are susceptible to linezolid. ${ }^{6,10-13}$

\section{Anaerobic bacteria}

Several Gram-positive and Gram-negative anaerobic bacteria are susceptible to linezolid, including many strains of Clostridium difficile, ${ }^{14,15}$ Fusobacterium spp., ${ }^{16}$ Prevotella spp. ${ }^{17}$ and Bacteroides spp. ${ }^{18}$ Linezolid is active against some strains of Actinomyces spp. ${ }^{19}$

\section{Mycobacteria}

Linezolid is active against Mycobacterium tuberculosis and several atypical mycobacteria. In general, the slow-growing mycobacteria are susceptible to linezolid, although some, such as $M$. avium Complex (MAC), are usually resistant. ${ }^{20}$
Rapidly growing atypical mycobacteria are less susceptible and MICs need to be determined. ${ }^{21}$

\section{Mode of action}

Linezolid inhibits protein synthesis by binding to domain $\mathrm{V}$ of the $23 \mathrm{~S}$ ribosomal RNA (rRNA) of the $50 \mathrm{~S}$ subunit of bacterial ribosomes; ${ }^{22}$ it has been shown to bind to the peptidyltransferase center (PTC) of the bacterial ribosome. ${ }^{23,24}$

\section{Resistance to linezolid}

Resistance rates to linezolid are low. ${ }^{25,26}$ Linezolid resistance occurred in $<1 \%$ of $S$. aureus, CoNS, and enterococci isolates from the US between 2002 and 2009. ${ }^{27}$ Linezolid resistance in clinical isolates was first reported in Enterococcus faecium $^{28,29}$ and in $S$. aureus f $^{30}$ and has since been reported in CoNS, Enterococcus faecalis. and viridans streptococci. ${ }^{31-33}$ Resistance occurs most often due to point mutations in the $23 \mathrm{~S}$ rRNA drug target site. ${ }^{34}$ Mutations of $23 \mathrm{~S}$ have been reported in resistant $S$. aureus, ${ }^{34} \mathrm{CoNS},{ }^{35}$ and enterococci. ${ }^{29,34}$ The most frequent of these mutations is G2576T. ${ }^{36,37}$ Resistance usually develops after prolonged therapy with linezolid for serious infection, ${ }^{38}$ although nosocomial acquisition of both resistant enterococci ${ }^{39}$ and CoNS ${ }^{35}$ has been reported, including cases in patients with no prior treatment with linezolid. ${ }^{39}$ Resistance develops slowly, because nearly all bacteria possess multiple copies of the $23 \mathrm{~S}$ rRNA gene. ${ }^{36}$ It has been proposed that combination with a second antibacterial agent, particularly rifampicin or fusidic acid, may delay the emergence of linezolid resistance in $S$. aureus. ${ }^{40}$ More recently, linezolid resistance has been identified due to acquisition of a natural resistance gene, $c f r$ (chloramphenicol-florfenicol resistance). The product of the $c f r$ gene is a methyltransferase that catalyzes methylation of A2503 in the 23S rRNA gene of the large 50S ribosomal subunit, conferring resistance to chloramphenicol, florfenicol, and clindamycin. ${ }^{41}$ The first $c f r$-mediated, linezolid-resistant clinical isolate of MRSA was reported in $2007 .{ }^{42}$

\section{Pharmacokinetics}

\section{Absorption and bioavailability}

Linezolid is rapidly absorbed orally, with almost $100 \%$ bioavailability ${ }^{43}$ so that oral and intravenous (iv) doses are equivalent and no dose adjustment is needed when switching between the two routes of administration. Peak levels $\left(\mathrm{C}_{\max }\right)$ are reached 1-2 hours after an oral dose. ${ }^{44,45}$ Taking linezolid with high-fat food will decrease $\mathrm{C}_{\max }$ by approximately $20 \%$ and prolong the time taken to reach $\mathrm{C}_{\text {max }}$ by about 1-2 hours ${ }^{43}$ 
but will not affect the area under the serum concentrationtime curve (AUC). ${ }^{46}$

The oral absorption of linezolid is not affected by the co-administration of antacids. ${ }^{47}$

A recent study in eight adult cystic fibrosis $(\mathrm{CF})$ patients showed bioavailability to be reduced to approximately $85 \%$ in this patient group, ${ }^{48}$ possibly due to pancreatic enzyme deficiency.

The pharmacokinetics of linezolid are largely linear, with the $\mathrm{C}_{\max }$ and AUC being proportional to the dose over the therapeutic dose range; there is a slight amount of nonlinearity at high-dose ranges, where a decrease in clearance is observed. ${ }^{46}$ The pharmacokinetic/pharmacodynamic parameters that are most predictive of efficacy for linezolid are the time above MIC ( $\mathrm{T}>\mathrm{MIC})$ and the ratio of the AUC to the MIC (AUC/MIC). ${ }^{46}$

Serum concentrations are above the $\mathrm{MIC}_{90}$ for susceptible pathogens for most of the dosing interval when given 12-hourly. ${ }^{49}$ However, linezolid levels have been found to be variable $e^{50,51}$ and may be suboptimal in some patient populations. ${ }^{52}$ Plasma linezolid concentrations in elderly patients, patients with mild-to-moderate hepatic impairment or mild to severe renal impairment are similar to those achieved in young or healthy volunteers. ${ }^{46,53}$

\section{Distribution and tissue penetration}

Linezolid is approximately $31 \%$ protein bound ${ }^{54}$ which is not concentration dependent. The volume of distribution is approximately 40-50 L, ie, approximately total body water content. ${ }^{50}$

\section{Skin, fat, and musculoskeletal tissues}

There is good penetration of linezolid into skin blister fluid ${ }^{44}$ indicating good tissue penetration. High linezolid levels have been demonstrated in adipose tissue and skeletal muscle. ${ }^{55}$ Other studies have shown that linezolid penetrates well into bone, muscle, and tissues surrounding infected prosthetic joints. $^{56,57}$

\section{Respiratory tissues}

Linezolid has been shown to penetrate well into lung epithelial lining fluid of patients with ventilator-associated pneumonia (VAP), ${ }^{58}$ those undergoing diagnostic bronchoscopy, ${ }^{59}$ and healthy volunteers. ${ }^{60}$ The study by Conte et $\mathrm{al}^{60}$ showed much less penetration into alveolar cell fluid.

\section{Central nervous system}

Linezolid penetration into cerebrospinal fluid (CSF) has been investigated in several studies. Tsona et al looked at
CSF levels after a single iv dose of $600 \mathrm{mg}$ linezolid in 18 patients undergoing neurosurgery. ${ }^{61}$ Mean concentrations of linezolid in serum, CSF, and brain tissue were assayed by high-performance liquid chromatography (HPLC); CSF/serum and brain/serum ratios were $69.57 \%$ and $44.66 \%$, respectively. Concentrations of linezolid were above the $\mathrm{MIC}_{90}$ for staphylococci and for streptococci. Boak et al also reported good penetration of linezolid into CSF in a patient with CoNS ventriculitis ${ }^{62}$ and Myrianthefs et al reported good linezolid concentrations in the CSF of patients receiving linezolid for treatment or prophylaxis of CNS infections. ${ }^{63}$ Beer et al measured linezolid levels in the serum and CSF of five patients with extraventricular devices (EVDs) and staphylococcal ventriculitis receiving linezolid $600 \mathrm{mg}$ twice daily iv. ${ }^{64}$ The mean CSF:plasma ratio was $0.8 \pm 0.3$. Times above the MIC in CSF were $99.8 \%$ and $57.2 \%$ for pathogens with MICs of $2 \mathrm{mg} / \mathrm{L}$ and $4 \mathrm{mg} / \mathrm{L}$, respectively. However, Viaggi et al measured plasma and CSF linezolid concentrations by HPLC after the 1 st and 5 th dose of linezolid in seven patients with external ventricular drainage, who received linezolid $600 \mathrm{mg}$ iv infusions twice daily to prevent CNS infections. ${ }^{65} \mathrm{CSF}$ AUC (range 18.2-85.5 and 19.6-160.5 $\mathrm{h} \times \mathrm{mg} / \mathrm{L}$ at the 1 st and 5 th dose, respectively) were lower than those calculated in plasma (range 27.6-224.0 and 27.5-166.1 $\mathrm{h} \times \mathrm{mg} / \mathrm{L}$, respectively). For $\mathrm{MIC}=1 \mathrm{mg} / \mathrm{L}, \mathrm{CSF}$ AUC/MIC values were nearly equal to or greater than 100 only in two subjects after the 1st and 5 th dose, whereas $\mathrm{T}>\mathrm{MIC}$ values were higher than $75 \%$ in only three patients.

\section{Eyes}

Linezolid has been shown to reach good levels in the aqueous humor of patients after a single oral or iv $600 \mathrm{mg}$ dose prior to routine cataract surgery. ${ }^{66,67}$

\section{Other tissues}

Linezolid has also been shown to have good penetration into the interstitial fluid of critically ill patients, ${ }^{68}$ the pancreatic fluid of patients with pancreatic abscesses, ${ }^{69}$ and the peritoneal dialysis fluid of a patient with peritonitis. ${ }^{70}$ Dehghanyar et al showed that linezolid in the tissues of healthy volunteers reached concentrations sufficient to inhibit the growth of pathogens with MICs up to $4 \mathrm{mg} / \mathrm{L}$, including MRSA and VRE, throughout the dose interval, although they also observed large variations in tissue linezolid concentrations between individuals, suggesting that in some individuals, some pathogens with MICs of $2 \mathrm{mg} / \mathrm{L}$ or higher would not be optimally inhibited. ${ }^{71}$ 


\section{Breast milk}

Linezolid can be detected in breast milk after oral administration. ${ }^{72}$

\section{Biofilms}

Treatment of biofilm-associated infections is a major problem associated with medical implants. Several studies have attempted to look at the role of linezolid in the treatment of biofilm-associated infections. Wilcox et al looked at biofilm concentrations of linezolid and of vancomycin in Grampositive catheter-associated biofilms after perfusion of the catheter lumens with antibiotics; ${ }^{73}$ they found vancomycin concentrations were generally greater than linezolid concentrations after a single exposure but neither antibiotic achieved consistent $100 \%$ kill of biofilm bacteria after single infusions, even when a very high concentration was present.

Wiederhold et al looked at the antibiotic activity of linezolid and vancomycin in vitro against Gram-positive bacteria in catheter-associated biofilms and found neither completely eradicated bacterial colonization of the catheters. Both linezolid and vancomycin suppressed bacterial growth of S. aureus and S. epidermidis compared with controls, while linezolid also suppressed counts compared with control and vancomycin versus VRE. ${ }^{74}$

Bayston et al investigated the effect of penicillin G, linezolid, and rifampicin on Propionibacterium acnes in biofilms. ${ }^{75}$ They demonstrated 14 days' treatment with penicillin $\mathrm{G}$, linezolid, or linezolid/rifampicin combination eradicated the growth of $P$. acnes whereas only penicillin $\mathrm{G}$ had this effect after just 7 days' treatment. After 9 days' re-incubation, the biofilms were re-cultured to detect "relapse"; penicillin $\mathrm{G}$ and linezolid/rifampicin showed no relapse but linezolid alone showed relapse growth at 14 days $(P<0.001)$.

Leite et al studied the susceptibility of $S$. epidermidis in biofilms to daptomycin, linezolid, and rifampicin in vitro by measuring colony-forming unit (CFU) reductions at MIC and peak serum concentrations. ${ }^{76}$ There was less CFU reduction with linezolid than with the other two antibiotics at peak serum concentrations and MICs.

Bayston et al looked at the actions of linezolid or vancomycin on biofilms of MRSA, MRSE, E. faecalis, and E. faecium on ventriculoperitoneal shunts. ${ }^{77}$ They found both linezolid and vancomycin caused eradication of staphylococci after 14 days of treatment at concentrations achievable in CSF and prevented its re-growth in the next 14 days, whereas neither antibiotic led to eradication or prevented re-growth of enterococci. Holmberg et al assessed the in vitro susceptibility of four isolates of E. faecalis from prosthetic knee and hip joints. ${ }^{78}$ The minimum bacterial eradication concentrations (MBECs) were determined for ampicillin, vancomycin, linezolid, ciprofloxacin, and rifampicin, alone and in combinations, and were found to be reduced for linezolid and for ciprofloxacin if combined with rifampicin, compared with uncombined treatment. The combination of ciprofloxacin and rifampicin was most effective at reducing bacterial growth, measured as CFU after 8 hours' exposure of the biofilm to the antibiotic(s), followed by the linezolid/ rifampicin combination. Sandoe et al looked at the antibiotic activity of linezolid, ampicillin, and vancomycin against 58 enterococcal isolates from biofilms and found the majority demonstrated tolerance (defined as $\mathrm{MBC} / \mathrm{MIC}>/=32$ ), that very high concentrations of all the antibiotics tested were needed to inhibit enterococcal biofilms in vitro and that the addition of gentamicin to any of the antibiotics only led to a significant reduction in MIC and MBC for some of the isolates. $^{79}$

\section{Excretion}

About $30 \%$ of linezolid is excreted unchanged in the urine the remainder undergoes renal and non-renal metabolism; it is oxidized to two main inactive metabolites. ${ }^{50}$ About $55 \%$ is excreted in the urine as metabolites and $10 \%$ in feces as metabolites. ${ }^{45,46}$ The plasma elimination half-life is $4.5-5.5$ hours. $^{45}$

Renal clearance is about $30-50 \mathrm{~mL} /$ minute in healthy volunteers, while non-renal clearance varies between $70-150 \mathrm{~mL} /$ minute. ${ }^{45}$ No dose adjustment is necessary in renal impairment ${ }^{80}$ or in mild-to-moderate liver impairment. ${ }^{81}$ In patients who are undergoing renal dialysis and who are being treated with linezolid, the dose should be given after a dialysis session as $30 \%-40 \%$ is removed by dialysis. ${ }^{82}$ A significant amount of linezolid is also removed by continuous venovenous hemofiltration $(\mathrm{CVVH})^{83}$ but no dose adjustment is currently recommended. ${ }^{84}$ However, the study of Meyer et al showed that, for pathogens with an MIC up to $4 \mathrm{mg} / \mathrm{L}$, the $\mathrm{T}>\mathrm{MIC}$ was $57 \%( \pm 32 \%)$ in $\mathrm{CVVH}$ patients receiving a standard dosage regimen of $600 \mathrm{mg}$ linezolid twice daily, compared to a T > MIC of $93 \%$ for pathogens with an MIC of $2 \mathrm{mg} / \mathrm{L}$, suggesting that some patients with less susceptible pathogens might benefit from an 8-hourly dosing regimen instead of 12-hourly. ${ }^{83}$

Linezolid clearance is higher in children than in adults, with a greater volume of distribution, shorter half-life, and smaller AUC, ${ }^{85}$ and therefore higher daily dosages are required in children. Clearance declines with age but no further dose adjustment with age is required. ${ }^{50}$ 


\section{Pharmacodynamics}

Linezolid is predominantly bacteriostatic in vitro against staphylococci and enterococci at concentrations of 2-10 times the $\mathrm{MIC}^{50,86}$ and at higher concentrations. ${ }^{87}$ Some bactericidal activity has been reported for linezolid against $S$. pneumoniae and S. pyogenes.$^{88}$ Bacteriocidal activity has also been reported in a rabbit model of $S$. aureus endocarditis when the linezolid was given as a continuous infusion instead of intermittent doses.

Linezolid has a short post-antibiotic effect against S. aureus, enterococci, and S. pneumonia. ${ }^{89}$

\section{Dosage}

The approved dose of linezolid in adults is $600 \mathrm{mg}$ orally or intravenously every 12 hours. The dose for children under 12 years old is $10 \mathrm{mg} / \mathrm{kg}$ three times daily. ${ }^{85}$

\section{Efficacy studies}

See table 1 for summary of efficacy studies.

\section{Bacteremia}

Wilcox et al looked at the use of linezolid vs teicoplanin ${ }^{90}$ in a randomized, controlled, open-label, multicenter study of 430 patients with suspected or proven Gram-positive infection. Patients were treated with linezolid or teicoplanin for up to 28 days. Clinical cure rates for the patients with bacteremia were statistically significantly higher between the two treatment arms $(88.5 \%$ vs $56.7 \%, P=0.009,95 \%$ confidence interval [CI]: 10.2-53.4). A Phase III study by Wilcox et al compared linezolid with vancomycin treatment of complicated skin and soft-tissue infections (cSSTIs) and catheter-related bloodstream infections in an open-label, multicenter, comparative study. ${ }^{91}$ They concluded that microbiological success with linezolid was noninferior to that with vancomycin in patients with cSSTIs and catheter-related bloodstream infections caused by Gram-positive organisms.

A meta-analysis by Falagas et al concluded that treatment with linezolid had significantly better success rates than treatment with comparator drugs in patients with Grampositive bacteremia ( $81.3 \%$ vs $66.4 \%){ }^{92}$

A meta-analysis by Beibei et al looked at results from 271 evaluable patients in three RCTs where linezolid was used to treat patients with bacteremia and found no statistically significant difference in treatment success between those receiving linezolid or vancomycin ${ }^{93}$

Jang et al compared salvage treatment with linezolid (+/- a carbapenem) to vancomycin (+gentamicin or rifampicin) in a small open-label retrospective study of 35 patients with persistent MRSA bacteremia. ${ }^{94}$ Nineteen patients, including four with positive hetero-Vancomycin-intermediate Staphylococcus aureus (VISA) screening tests, received vancomycin-based treatment and 16 patients received linezolid-based treatment. The early microbiological response (ie, negative follow-up blood culture within 72 hours) was significantly higher in the linezolid-based salvage therapy group than the vancomycinbased group ( $75 \%$ vs $17 \% ; P=0.006)$. The salvage success rate was higher for linezolid therapy than for vancomycinbased combination therapy $(P<0.001)$; linezolid-based therapy gave an $88 \%$ salvage success rate.

\section{Skin and soft tissue infection (SSTI)}

Several randomized clinical trials have been carried out comparing the efficacy of linezolid with comparator drugs for the treatment of SSTI. Jauregui et al compared linezolid 12-hourly for 14 days to dalbavancin once weekly (two doses) for the treatment of SSTI, including infections with MRSA, in 854 patients in a Phase III multicenter, double-blind RCT. ${ }^{95}$ Efficacy was assessed by clinical and microbiological responses. Dalbavancin and linezolid demonstrated comparable clinical efficacy in the clinically evaluable population at the test-ofcure visit ( $88.9 \%$ and $91.2 \%$ success, respectively). Weigelt et al compared linezolid to vancomycin in the treatment of 1200 patients with proven or suspected MRSA complicated SSTIs (cSSTIs) in an open-label RCT. ${ }^{96}$ The results showed linezolid was more effective than vancomycin (based on test-of-cure visit) in patients with abscesses and in those with MRSA infections. Wilcox et al compared clinical success at end-of-treatment visit in patients who received linezolid (117 patients) or teicoplanin (111 patients) for the treatment of Gram-positive SSTI, and found no statistical significance between the two groups. ${ }^{90}$ Stevens et al carried out a randomized, double-blind, multicenter trial comparing the efficacy of linezolid with that of oxacillin in 826 patients with complicated SSTIs and found that linezolid was as effective as oxacillin in the treatment of these infections. ${ }^{97} \mathrm{~A}$ meta-analysis of RCTs by Falagas et al found linezolid was significantly more effective in treating SSTIs than comparators (beta-lactams or glycopeptides) ( $90.3 \%$ vs $85.7 \%$ success of treatment). ${ }^{92} \mathrm{~A}$ meta-analysis of RCTs by Beibei et al concluded that linezolid was more effective treatment than vancomycin in patients with SSTIs (odds ratio [OR]: 1.40, 95\% CI: 1.01-1.95) ${ }^{93}$ Bounthavong and Hsu evaluated the clinical and microbiological outcomes of linezolid compared to vancomycin in MRSA cSSTIs using a meta-analysis of five studies with a total of 2652 patients (1361 linezolid; 1291 vancomycin) and concluded that linezolid was more likely to achieve microbiological eradication of MRSA than vancomycin in these infections. ${ }^{98}$ 
Table I Summary of efficacy studies/reports

\begin{tabular}{|c|c|c|c|}
\hline Author & $\begin{array}{l}\text { Study design/ } \\
\text { case details }\end{array}$ & $\begin{array}{l}\text { Antibiotic (linezolid } \\
\text { or comparator drugs) }\end{array}$ & Results/conclusions \\
\hline \multicolumn{4}{|l|}{ Bacteraemia } \\
\hline Wilcox et $\mathrm{al}^{90}$ & $\begin{array}{l}\text { RC, OL, MC, } 430 \text { pts with } \\
\text { GP infections, } 56 \text { with bacteremia }\end{array}$ & Teicoplanin for up to 28 days & $\begin{array}{l}\text { Clinical cure rates for bacteremia patients } 88.5 \% \\
\text { (linezolid) vs } 56.7 \% \text { (teicoplanin) } P=0.009\end{array}$ \\
\hline Wilcox et al ${ }^{91}$ & $\begin{array}{l}\text { Phase III, OL, MC } \\
\text { Patients with GP cSSTI and CRBSI }\end{array}$ & Vancomycin & $\begin{array}{l}\text { Non-inferiority of linezolid in microbiological } \\
\text { success }\end{array}$ \\
\hline Jang et $\mathrm{al}^{94}$ & $\begin{array}{l}\text { Salvage therapy in } 35 \text { patients } \\
\text { with persistent MRSA bacteremia, } \\
\text { OL, retrospective }\end{array}$ & $\begin{array}{l}\text { Linezolid }+/- \text { carbapenem vs } \\
\text { vancomycin }+ \text { (gentamicin or } \\
\text { rifampicin) }\end{array}$ & $\begin{array}{l}\text { EMR higher in linezolid-treated pts than } \\
\text { vancomycin-treated patients }(75 \% \text { vs } 17 \% \\
P=0.006) . \text { Salvage success rate in linezolid } \\
\text { patients }(88 \%) \text { significantly higher than in } \\
\text { vancomycin pts }(P<0.00 \text { I) }\end{array}$ \\
\hline Falagas and Vardakas ${ }^{|3|}$ & Meta-analysis: 255 pts in 5 RCTs & $\beta$-lactams and glycopeptides & $\begin{array}{l}\text { Success rates in GP bacteraemia } 81.3 \% \text { (linezolid) } \\
\text { vs } 66.4 \% \text { (comparator) }\end{array}$ \\
\hline Beibei et $\mathrm{al}^{93}$ & Meta-analysis: $27 \mathrm{I}$ pts in $3 \mathrm{RCTs}$ & Vancomycin & $\begin{array}{l}\text { No statistically significant difference in treatment } \\
\text { success in bacteremia patients between linezolid } \\
\text { and vancomycin }\end{array}$ \\
\hline \multicolumn{4}{|c|}{ Skin and soft tissue infections } \\
\hline Jauregui et al $^{95}$ & 854 pts, phase III MC, DB, RCT & Dalbavancin & No significant difference in efficacy: $88.9 \%$ vs $91.2 \%$ \\
\hline Weigelt et $\mathrm{al}^{96}$ & I 200 pts OL RCT & Vancomycin & $\begin{array}{l}\text { Linezolid more effective than vancomycin in pts } \\
\text { with abscesses and those with MRSA }\end{array}$ \\
\hline Wilcox et $\mathrm{al}^{90}$ & 228 pts, GP SSTI & Teicoplanin & No statistical difference \\
\hline Stevens et $\mathrm{al}^{97}$ & 826 pts RCT, DB, MC & Oxacillin & Linezolid as effective as oxacillin in treatment of cSSTI \\
\hline Falagas and Vardakas ${ }^{|3|}$ & Meta-analysis: $266 \mathrm{I}$ pts in $8 \mathrm{RCTs}$ & $\beta$-lactams and glycopeptides & $\begin{array}{l}\text { Linezolid significantly more effective than } \\
\text { comparators } 90.3 \% \text { vs } 85.7 \% \text { success }\end{array}$ \\
\hline Biebei et $\mathrm{al}^{93}$ & Meta-analysis: $27 \mathrm{I}$ pts in 3 RCTs & Vancomycin & $\begin{array}{l}\text { linezolid more effective treatment than } \\
\text { vancomycin }(\mathrm{OR}=\mathrm{I} .40,95 \% \mathrm{Cl} \mathrm{I} .0 \mathrm{I}-\mathrm{I} .95)\end{array}$ \\
\hline Bounthavong and $\mathrm{Hsu}^{98}$ & $\begin{array}{l}\text { Meta-analysis of } 5 \text { studies, } \\
2652 \text { pts, MRSA cSSTIs }\end{array}$ & Vancomycin & $\begin{array}{l}\text { Linezolid more likely to achieve microbiological } \\
\text { eradication of MRSA than vancomycin in MRSA } \\
\text { cSSTI infections }\end{array}$ \\
\hline \multicolumn{4}{|l|}{ Pneumonia } \\
\hline San Pedro et al ${ }^{100}$ & 747 pts with CAP, MC, OL, RCT & $\begin{array}{l}\text { Linezolid }+/ \text { - aztreonam vs } \\
\text { ceftriaxone/cefpodoxime }\end{array}$ & $\begin{array}{l}\text { Higher cure rate overall in the linezolid-treated } \\
\text { patients }(83 \% \text { vs } 76.4 \% P=0.04) \\
\text { Of } 254 \text { patients with S pneumoniae, no significant } \\
\text { difference in cure rates; sub-group with } \\
\text { S pneumoniae bacteraemia had significantly better } \\
\text { cure rate in linezolid arm }(93.1 \% \text { vs } 68.2 \% \text {; } \\
P=0.021)\end{array}$ \\
\hline Walkey et al ${ }^{101}$ & Meta-analysis: 1641 pts in 8 trials & Glycopeptides & $\begin{array}{l}\text { Linezolid not superior to glycopeptides for } \\
\text { suspected MRSA nosocomial pneumonia. }\end{array}$ \\
\hline Falagas and Vardakas ${ }^{|3|}$ & Meta-analysis: 864 pts in 7 RCTs & $\beta$-lactams and glycopeptides & $\begin{array}{l}\text { No significant difference in outcomes in patients } \\
\text { with GP pneumonia or nosocomial pneumonia. }\end{array}$ \\
\hline Wunderink et al ${ }^{102}$ & $\begin{array}{l}\text { Prospective DB, MC RCT } \\
348 \text { pts with MRSA pneumonia }\end{array}$ & $\begin{array}{l}\text { Vancomycin (dose adjusted } \\
\text { as per trough levels) }\end{array}$ & $\begin{array}{l}\text { Linezolid treatment had higher clinical success } \\
\text { rates than vancomycin treatment; } 95 / 165(57.6 \%) \\
\text { vs } 81 / 174(46.6 \%) P=0.042) \text { in evaluable per } \\
\text { protocol pts }\end{array}$ \\
\hline \multicolumn{4}{|c|}{ Bone and joint infections } \\
\hline Aneziokoro et al ${ }^{105}$ & Retrospective in 20 patients & Linezolid for $6+$ weeks & $55 \%$ clinical cure rate in osteomyelitis \\
\hline Rayner et al ${ }^{106}$ & Compassionate use in 22 patients & Linezolid & $82 \%$ clinical cure rate in osteomyelitis \\
\hline \multicolumn{4}{|l|}{ Endocarditis } \\
\hline Falagas et $\mathrm{al}^{1 / 2}$ & $\begin{array}{l}\text { Systemic review of use in } \\
33 \text { patients }\end{array}$ & Linezolid $+/$ - other & $\begin{array}{l}\text { Linezolid is potentially useful for endocarditis, } \\
\text { including after vancomycin failure }\end{array}$ \\
\hline \multicolumn{4}{|l|}{ CNS } \\
\hline Zeana et al ${ }^{1 / 8}$ & Case report & Linezolid & VRE \\
\hline Faella et al ${ }^{119}$ & Case report & Linezolid & PRP \\
\hline Ramirez et al $\left.\right|^{120}$ & Case report & Linezolid & PRP after vancomycin failure \\
\hline Leiti et $\mathrm{al}^{|2|}$ & Case report & Linezolid + rifampicin & $L$ monocytogenes brain abscess \\
\hline Viganò et al ${ }^{122}$ & Case report & Lineolid & Nocardial brain abscess \\
\hline
\end{tabular}


Table I (Continued)

\begin{tabular}{|c|c|c|c|}
\hline Author & $\begin{array}{l}\text { Study design/ } \\
\text { case details }\end{array}$ & $\begin{array}{l}\text { Antibiotic (linezolid } \\
\text { or comparator drugs) }\end{array}$ & Results/conclusions \\
\hline \multicolumn{4}{|l|}{ Febrile Neutropenia } \\
\hline Jaksic et al ${ }^{123}$ & DB RCT & Vancomycin Ig bd $10-28$ days & $\begin{array}{l}\text { Similar clinical success rates and safety profiles } \\
\text { between linezolid and vancomycin groups }\end{array}$ \\
\hline \multicolumn{4}{|c|}{ Mycobacterial Infections } \\
\hline Nannini et al ${ }^{124}$ & Case report in patient with CLL & $\begin{array}{l}\text { Part of combination treatment } \\
\text { including moxifloxacin }\end{array}$ & Disseminated MAC infection \\
\hline Kyle and Porter ${ }^{125}$ & Case report & $\begin{array}{l}\text { Part of combination treatment } \\
\text { with clarythromicin }\end{array}$ & M chelonae infection \\
\hline Ntziora and Falagas ${ }^{126}$ & Review of 24 cases & Part of combination treatment & $\begin{array}{l}\text { May be beneficial in combination treatment } \\
\text { for Mycobacterial infections, including } \\
M \text { tuberculosis,but long-term use often limited } \\
\text { by drug-related adverse effects. }\end{array}$ \\
\hline
\end{tabular}

Abbreviations: MC, multi-centre; RCT, randomized controlled trial; OL, open-label; DB, double-blind; GP, gram positive; cSSTI, complicated skin and soft tissue infection; CRBSI, catheter-related blood stream infection; EMR, early microbiological response; MAC, $M$ avium Complex; CLL, chronic lymphocytic leukaemia; CAP, communityacquired pneumonia; PRP, penicillin resistant pneumococcus; VRE, vancomycin resistant enterococcus; MRSA, methicillin resistant Staphylococcus aureus; bd, twice daily.

\section{Pneumonia}

The efficacy of linezolid in the treatment of both community acquired pneumonia (CAP) and hospital acquired pneumonia (HAP) has been investigated in many trials. It has been shown to penetrate well into the lung epithelial lining fluid of healthy volunteers ${ }^{60}$ and patients with VAP ${ }^{58}$ and into parapneumonic pleural effusions. ${ }^{99}$ San Pedro et al compared linezolid (+/-aztreonam) to iv ceftriaxone followed by oral cefpodoxime for the treatment of CAP, in 747 patients in a multicenter, randomized, open-label trial. ${ }^{100}$ There was a higher cure rate overall in the linezolid-treated patients ( $83 \%$ vs $76.4 \%$; $P=0.04$ ). However, of the 254 patients with $S$. pneumoniae isolated, there was no significant difference in cure rates between the two arms, except in the subgroup with $S$. pneumoniae bacteremia, where the linezolid-treated group had a superior clinical cure rate $(93.1 \%$ vs $68.2 \% ; P=0.021)$.

A meta-analysis of trials by Walkey et al compared treatment with glycopeptides to linezolid for suspected MRSA nosocomial pneumonia, using data from 1641 patients in eight trials and concluded that linezolid was not superior to glycopeptides for these patients. ${ }^{101}$ A meta-analysis of RCTs by Falagas et al found no significant difference between linezolid or comparator drug in patients with Gram-positive pneumonia or nosocomial pneumonia. ${ }^{92}$

Wunderink et al carried out a prospective, double-blind, multicenter RCT of adult patients with nosocomial MRSA pneumonia treated with linezolid or with a dose-optimized vancomycin regimen where the vancomycin dose was adjusted on the basis of trough levels. ${ }^{102}$ In the evaluable per-protocol patients, 95/165 (57.6\%) linezolid-treated patients and 81/174 (46.6\%) vancomycin-treated patients achieved clinical success which was statistically significant (95\% CI: $0.5 \%-21.6 \% ; P=0.042$ ).

\section{Bone and joint infections}

Linezolid has good penetration into bone and surrounding tissue $^{103}$ and it has been used to treat osteomyelitis, septic arthritis, and prosthetic joint infections due to several microorganisms, including MRSA, CoNS, VRE, and VISA, either alone or in combination. ${ }^{69,104}$ Aneziokoro et al looked retrospectively at the clinical effectiveness of at least 6 weeks of oral linezolid therapy for osteomyelitis. ${ }^{105}$ The clinical cure rate was $55 \%$ for the 20 patients who received at least 6 weeks of therapy. Rayner et al looked at the results of linezolid treatment of osteomyelitis in patients in a compassionate use program; of 22 patients evaluable, there was an $82 \%$ clinical cure rate. ${ }^{106}$

\section{Endocarditis}

Despite its bacteriostatic rather than bactericidal action, linezolid has been used to treat endocarditis, particularly where multiresistant organisms are involved. Animal experiments have suggested linezolid may be effective at treating MRSA endocarditis if plasma concentrations of linezolid are above the MIC of the organism ${ }^{107}$ and that it may be useful in VRE endocarditis. ${ }^{108}$ Several case reports of the use of linezolid to treat endocarditis due to resistant organisms have been published, with varying success reported. ${ }^{104,109-111}$ Falagas et al carried out a systematic review of the use of linezolid in the treatment of endocarditis, either as a single agent or in combination with other antibiotics. ${ }^{12}$ Results from 33 patients were included, most with MRSA or VISA. They concluded that linezolid is potentially useful as a treatment option for endocarditis where other treatments are limited, including cases where vancomycin treatment has failed. A combination of linezolid with gentamicin has been shown to be bactericidal when used in an experimental model of MRSA endocarditis. ${ }^{113}$ 


\section{Central nervous system}

There have been several case reports of the successful use of linezolid in the treatment of post-neurosurgical and posttraumatic CNS infections. ${ }^{114-116}$ Linezolid has been shown to have good penetration into the CSF. ${ }^{61,117}$ Linezolid has also been used to treat CNS infections caused by resistant organisms, including by VRE ${ }^{118}$ and by PRP, ${ }^{119}$ including treatment of PRP after failure of vancomycin. ${ }^{20}$ There have been case reports of the successful use of linezolid with rifampicin to treat a brain abscess due to L. monocytogenes ${ }^{121}$ and of its use to successfully treat Nocardial brain abscesses. ${ }^{122}$

\section{Febrile neutropenia}

Jaksic et al compared the clinical outcomes in cancer patients with febrile neutropenia treated with linezolid $600 \mathrm{mg}$ twice daily or with vancomycin $1 \mathrm{~g}$ twice daily in a DB RCT; ${ }^{123}$ clinical success rates 7 days after the completion of therapy were equivalent in the two groups, with similar safety profiles.

\section{Mycobacterial infections}

Linezolid has been shown to have in vitro activity against some mycobacteria. There have been case reports of its success use in combination treatments of a disseminated $M$. avium complex infection refractory to first-line treatment ${ }^{124}$ and of a M. chelonae infection. ${ }^{125}$ Ntziora and Falagas reviewed its use in the treatment of mycobacterial infections, including M. tuberculosis, and concluded that it may be beneficial in combination treatment in some cases but that its long-term use in such cases is limited by the development of serious adverse reactions. ${ }^{126}$

\section{Safety and tolerability}

The majority of adverse events develop after prolonged administration (ie, $>2$ weeks) and subside shortly after discontinuation of linezolid. Adverse events associated with linezolid treatment are summarized in table 2.

Minor side effects were seen more commonly than with comparators in Phase III clinical trials: linezolid has been investigated in several comparator-controlled trials, including against ceftriaxone, ${ }^{100}$ vancomycin, ${ }^{127,128}$ and oxacillin ${ }^{97}$ and had a significantly higher incidence of non-serious side effects including nausea, headache, and vomiting. ${ }^{129}$ The most common adverse event recorded in those taking linezolid was diarrhea, which occurred in $4.3 \%$ patients on linezolid, however, this was not significantly greater than in patients on the comparator drugs. ${ }^{129} \mathrm{~A}$ Phase III randomized, comparator-controlled study in children aged 0-12 years receiving vancomycin or linezolid for a variety of infections showed linezolid to be better tolerated than vancomycin, with significantly more drug-related adverse events in those taking vancomycin; the most commonly reported adverse events for linezolid were fever (14\%), diarrhea (11\%), and vomiting $(9 \%) .{ }^{130}$ Other adverse events potentially related to linezolid therapy include fungal infections (moniliasis), tongue discoloration and taste alterations, dizziness, insomnia, rash, and C. difficile-related diarrhea. ${ }^{131}$

\section{Allergic reactions}

Immediate hypersensitivity reactions to linezolid have been rarely reported. ${ }^{132}$ Delayed hypersensitivity reactions are also rare, including angioedema and rash. ${ }^{133,134}$ Cases of interstitial nephritis and DRESS syndrome have been reported. ${ }^{135,136}$

\section{Lactic acidosis}

Linezolid has been reported to be associated with lactic acidosis in both adults ${ }^{137}$ and children. ${ }^{138}$ It is most commonly reported after prolonged administration of linezolid and resolves when linezolid is stopped ${ }^{133,137}$ but there have been case reports of lactic acidosis occurring early on during linezolid treatment. ${ }^{139,140}$ Linezolid is proposed to cause hyperlactatemia by inhibiting mitochondrial protein synthesis: ${ }^{141}$ it has been shown that oxazolidinones are able to bind to human mitochondrial ribosomes ${ }^{24}$ and that prolonged linezolid treatment can reversibly inhibit mitochondrial protein synthesis. ${ }^{142}$ It is possible that some patients are more susceptible to developing linezolid-induced lactic acidosis due to mitochondrial DNA polymorphisms. ${ }^{143}$

\section{Hematological}

Preclinical animal studies and Phase I healthy volunteer trials showed a moderate, reversible, dose-dependent decrease in red cell and platelet indices. ${ }^{144}$ There have been several case reports of myelosuppression, including thrombocytopenia and anemia, with linezolid treatment, and one case report of reversible pure red cell aplasia after 8 weeks of linezolid treatment. ${ }^{145}$ Atassi et al observed a decrease in platelets by at least $30 \%$ from baseline in $47 \%(9 / 19)$ patients in a single center retrospective case series. ${ }^{146}$ However, results from comparator clinical trials are conflicting, with some demonstrating a myelosuppressive effect of linezolid compared to comparator drug, and others showing no difference in myelosuppression in patients on linezolid from those on comparator drug. Gerson et al looked at the hematological indices in patients on linezolid and on comparator drugs in seven clinical trials, with over 2000 patients in each arm, and 
Table 2 Summary of adverse events associated with linezolid treatment

\begin{tabular}{|c|c|}
\hline Description & Comments \\
\hline \multicolumn{2}{|l|}{ Minor reactions } \\
\hline $\begin{array}{l}\text { Include diarrhea, nausea, headache, } \\
\text { taste disturbances, dizziness }\end{array}$ & Minor side-effects seen more commonly in phase III trials than with comparator drugs. ${ }^{129}$ \\
\hline \multicolumn{2}{|l|}{ Allergic reactions } \\
\hline Immediate hypersensitivity & Reaction after Ist dose of linezolid. ${ }^{132}$ \\
\hline Delayed hypersensitivity & Purpuric rash reported on day of 9 linezolid. ${ }^{133}$ \\
\hline Interstitial nephritis & Esposito et al. ${ }^{135}$ \\
\hline DRESS syndrome & Developed after day 7 of linezolid. ${ }^{136}$ \\
\hline \multicolumn{2}{|l|}{ Lactic acidosis } \\
\hline Increased blood lactate levels & Usually associated with prolonged linezolid treatment and resolves when linezolid is stopped. \\
\hline \multirow[t]{2}{*}{$(>4-5 \mathrm{mmol} / \mathrm{L})$ with metabolic acidosis } & Linezolid thought to cause lactic acidosis via inhibition of mitochondrial protein synthesis. \\
\hline & Some patients more susceptible due to polymorphisms in mitochondrial DNA. \\
\hline \multicolumn{2}{|r|}{ - } \\
\hline \multirow[t]{2}{*}{ Myelosuppresion } & $\begin{array}{l}\text { Effects are mainly on red cell and platelet lineages, usually moderate, reversible and dose-dependent in } \\
\text { case reports and phase I trials. }{ }^{14}\end{array}$ \\
\hline & $\begin{array}{l}\text { Conflicting results from CCTs and meta-analyses; some suggest increased incidence of hematological side- } \\
\text { effects compared to comparator drugs, }{ }^{149} \text { others suggesting no significant difference. }{ }^{147}\end{array}$ \\
\hline \multirow[t]{5}{*}{ Thrombocytopenia } & Commonest reported hematological side-effect. ${ }^{92}$ \\
\hline & Some reports suggest related to length of treatment. ${ }^{146}$ \\
\hline & Reports of more severe thrombocytopenia developing in patients with impaired renal function ${ }^{154}$ possibly \\
\hline & due to impaired renal clearance ${ }^{155}$ and higher linezolid AUC. ${ }^{156}$ \\
\hline & Has been used in HSCT patients without delaying platelet engraftment (Cohen et al $\left.\right|^{157}$ ). \\
\hline \multirow[t]{4}{*}{ Anemia } & Marrow appearances suggest anemia occurs due to bone marrow suppression (Bernstein et al ${ }^{150}$ ). \\
\hline & A transient delay in neutrophil recovery was reported in oncology patients with baseline marrow \\
\hline & suppression (Jaksic et al ${ }^{123}$ ) but it was not reflected in length of antibiotic treatment required. \\
\hline & Has been used in HSCT patients without delaying neutrophil engraftment. ${ }^{157}$ \\
\hline Pure red cell aplasia & I case report after 8 weeks linezolid. ${ }^{145}$ \\
\hline \multicolumn{2}{|l|}{ Hepatic dysfunction } \\
\hline Raised transaminases & $\begin{array}{l}\text { Meta-analysis of } 7 \text { comparator controlled trials found mean transaminase levels stayed within normal range } \\
\text { during treatment, and no significant difference in transaminases in patients receiving comparator drug. }{ }^{.29}\end{array}$ \\
\hline Microvesicular steatosis & Case report in a patient on prolonged linezolid treatment. ${ }^{158}$ \\
\hline \multicolumn{2}{|l|}{ Neurological toxicity } \\
\hline \multirow[t]{2}{*}{ Peripheral neuropathy } & Usually presents as parasthesia with sensory loss, often painful. \\
\hline & May be irreversible or take months to recover. ${ }^{160,161}$ \\
\hline \multirow[t]{3}{*}{ Optic neuropathy } & Presents with acute LOV, loss of colour vision and visual acuity. \\
\hline & Recovery occurs more often than peripheral neuropathy does. ${ }^{162}$ \\
\hline & Both types may co-exist and usually occur after prolonged treatment. ${ }^{159}$ \\
\hline Bell's Palsy & Case report. ${ }^{165}$ \\
\hline \multicolumn{2}{|l|}{ Cardiac } \\
\hline QTc interval & No effect in phase I studies. ${ }^{129}$ \\
\hline Pregnancy & No controlled studies performed. \\
\hline \multicolumn{2}{|l|}{ Drug interactions } \\
\hline Serotonin syndrome & $\begin{array}{l}\text { Potential interaction with serotinergic and adrenergic drugs because linezolid is a mild MAOI. Several case } \\
\text { reports of SS when co-administered with SSRIs. A retrospective review of patients concluded linezolid } \\
\text { and SSRIs may be taken concomitantly if monitored for development of SS. }{ }^{171} \text { Review of data from phase } \\
\text { III and IV CCTs found no increased risk of SS in patients on linezolid or comparator. } .^{170}\end{array}$ \\
\hline Cytochrome p450 interactions & Linezolid is not an inhibitor or substrate of $p 450 . .^{165}$ \\
\hline
\end{tabular}

Abbreviations: DRESS, drug rash with eosinophilia and systemic symptoms; LOV, loss of vision; MAOI, monoamine oxidase inhibitor; CCTs, comparator controlled trials; SS, serotonin syndrome; SSRI, selective serotonin re-uptake inhibitors; AUC, area under the time-concentration curve; HSCT, hemopoeitic stem cell transplant.

found no statistical difference in the occurrence of anemia or thrombocytopenia between the two patient sets. ${ }^{147}$ When thrombocytopenia was observed in linezolid-treated patients, it was usually in those who had received more than 2 weeks' treatment. There was a statistically significant decrease in reticulocyte indices in the linezolid group at the end of treatment but not at follow-up. Falagas et al carried out a meta-analysis of adverse events reported in $>4000$ patients in eight RCTs comparing linezolid to glycopeptides or beta-lactam treatment for a mean duration of 9-12 days and 
found significantly more thrombocytopenia in the linezolid arm (OR: 11.72; 95\% CI: 3·66-37.57), although there was not a standard definition of thrombocytopenia in the RCTs included. ${ }^{92}$ There was no significant difference in anemia between the two patient groups. Nasraway et al assessed the risk of thrombocytopenia in 686 patients with nosocomial pneumonia who received linezolid or vancomycin for at least 5 days in two randomized, double-blind studies and found no statistically significant differences between groups in new-onset thrombocytopenia (platelet count of $<150 \times 10^{9}$ platelets/L), severe thrombocytopenia (platelet count of $<50 \times 10^{9}$ platelets/L), or fall in platelet counts to less than the baseline. ${ }^{148}$ Weigelt et al found the incidence of reported thrombocytopenia (level not defined) was statistically more common in 592 patients receiving linezolid (mean 11.8 days) then 588 patients receiving vancomycin (mean 10.9 days) for cSSTIs in a randomized, open-label, multicenter study, ${ }^{149}$ occurring in $3.5 \%$ patients in the linezolid group.

Thrombocytopenia is the most commonly reported hematological adverse event and it has been proposed that it occurs due to an immune-mediated mechanism, based on bone marrow appearances, whereas anemia appears to be caused by suppression of normal erythropoiesis. ${ }^{150}$ Some authors have reported a relationship between onset of thrombocytopenia and length of linezolid treatment ${ }^{146,147}$ although others have not observed this. ${ }^{151}$ In a compassionate-use program, the incidence of adverse hematologic events was higher in patients who received $>14$ days of linezolid therapy. ${ }^{152}$ Kuter and Tillotson reported a median time to onset of thrombocytopenia of 17 days in spontaneous reports from postmarketing surveillance in the first 6 months of linezolid use. ${ }^{153}$

Linezolid appears to have a greater myelosuppressive effect in some patient groups; Lin et al found severe thrombocytopenia $\left(<100 \times 10^{9} / \mathrm{L}\right)$ was significantly more likely to develop in patients on linezolid with raised baseline creatinine levels than in those with normal creatinine baseline levels. ${ }^{154}$ It has been postulated that this may be related to decreased renal clearance of linezolid. ${ }^{155}$ Tsuji et al found a significant correlation between AUC and thrombocytopenia and anemia in renal dysfunction patients. ${ }^{156}$

Despite its hematological effects, linezolid appears not to have an increased risk of hematological adverse effects in patients with preexisting hematological abnormalities. Cohen et al looked at the effect of linezolid on the engraftment of platelets and neutrophils in patients undergoing hemopoeitic stem cell transplants (HSCT) in a retrospective, case-controlled study: linezolid was given for at least 7 days and was started before day +8 post-transplantation. The median duration of treatment was 14 days in the 33 linezolid-treated patients vs 16 days in the 33 vancomycin-treated patients with no significant differences between the two groups in times to neutrophil or platelet engraftment. ${ }^{157}$ Jaksic et al looked at the efficacy and safety of treatment with linezolid compared to vancomycin for febrile neutropenia in a randomized, doubleblind study of patients with cancer. ${ }^{123}$ They found there were fewer reported overall, including hematological, drug-related adverse events (17\% of 303 linezolid patients vs $24 \%$ of 300 vancomycin patients; $P=0.04$ ). Patients received $10-28$ days of the study antibiotic. Most of the patients had hematological malignancies with absolute neutrophil count (ANC) $<100$ cells $/ \mathrm{mm}^{3}$. Approximately $40 \%$ patients in each group received a colonystimulating factor during the study period. There was no difference in hematological adverse events between the groups in the intention to treat (ITT) populations. They did observe a transient delay in time to ANC recovery in the linezolid group compared to the vancomycin group, which was not reflected in the duration of antibiotic treatment. There was no difference in time to platelet recovery between the two groups $(P=0.8)$.

\section{Hepatic dysfunction}

Minor, reversible increases in alanine transaminase (ALT) and aspartame transaminase (AST) have been observed on linezolid treatment. A meta-analysis looking at safety data from seven controlled clinical trials comparing linezolid and comparator drugs for a variety of infections found the mean values of liver transaminases remained within the normal range throughout the course of the studies, with no statistically significant difference between linezolid and comparator drug groups. ${ }^{129}$ De Bus et al reported a case of severe liver toxicity with microvesicular steatosis in a patient on prolonged linezolid treatment. ${ }^{158}$

\section{Neurological toxicity}

Peripheral and optic neuropathy have been reported following linezolid treatment; prolonged use, usually for more than 1 month, seems to be an important risk factor. ${ }^{159}$ Both neuropathies may occur in the same patient. The peripheral neuropathy is often painful, requiring treatment with amitriptyline or gabapentin, and usually presents as parasthesia with sensory loss. Peripheral neuropathy may be irreversible or may resolve after linezolid is discontinued, sometimes taking several months for recovery. ${ }^{160,161}$ Optic neuropathy presents with acute loss of central vision, loss of colour vision, and visual acuity and seems more likely to recover after cessation of linezolid than peripheral neuropathy. ${ }^{162}$ Treatment with corticosteroids has produced no effect or worsening of 
symptoms in some cases. ${ }^{162}$ It has also been reported after short-term (16 days) linezolid use. ${ }^{163}$ A case of Bell's palsy in a patient on linezolid has been reported. ${ }^{164}$

\section{Cardiac}

Phase I studies in human volunteers have shown no effect of linezolid on QTc interval. ${ }^{129}$

\section{Pregnancy}

There have been no controlled studies in pregnant women.

\section{Drug interactions Cytochrome p450 drug interactions}

Linezolid is not a cytochrome p450 inhibitor or substrate. ${ }^{165}$

\section{Serotonin syndrome}

Linezolid is a mild, reversible, inhibitor of monoamine oxidase and can potentially interact with serotonergic and adrenergic agents to cause serotonin syndrome (SS) and hypertension. ${ }^{166}$ There have been several case reports of SS in patients receiving linezolid with concomitant selective serotonin re-uptake inhibitors (SSRI) ${ }^{167,168}$ although no cases were reported in pre-marketing trials when linezolid was co-administered with several potentially interacting drugs. ${ }^{169}$ Some authors have proposed that linezolid should not be used in patients who have been receiving SSRIs until the SSRI has been discontinued for 2 weeks, ${ }^{167}$ however, a review of data from Phase III and IV CCTs showed the risk of SS in patients on linezolid was no different from the risk in patients on comparator drugs. ${ }^{170} \mathrm{~A}$ retrospective review of patients receiving linezolid and concomitant SSRIs concluded that linezolid may be used concomitantly with SSRIs, with careful monitoring for signs and symptoms of serotonin syndrome and stopping the SSRI if SS was suspected. ${ }^{171}$

\section{Cost effectiveness}

Several analyses have looked at the cost effectiveness of treatment with linezolid compared to other drug for different indications.

Bounthavong et al carried out a cost effectiveness analysis of linezolid, daptomycin, and vancomycin in MRSA cSSTIs using a decision analytical model based on efficacy and safety parameters. ${ }^{172}$ The total direct costs of linezolid, daptomycin, and vancomycin were USD \$18,057, \$20,698, and $\$ 23,671$, respectively. The cost-effectiveness ratios for linezolid, daptomycin, and vancomycin were calculated to be $\$ 37,604, \$ 44,086$, and $\$ 52,663$ per successfully treated patient, respectively. They concluded that linezolid appears to be more cost effective compared to daptomycin and vancomycin for MRSA cSSTIs. Schürmann et al also evaluated the cost effectiveness of linezolid against vancomycin in the empirical treatment of cSSTI due to suspected MRSA. ${ }^{173}$ They concluded that the average total cost/episode was $€ 8,232$ for linezolid versus $€ 9,206$ for vancomycin; the higher acquisition cost of linezolid being offset by shorter inpatient stays and shorter lengths of iv treatment duration with linezolid compared to vancomycin.

De Cock et al compared the cost effectiveness of linezolid to vancomycin in suspected MRSA nosocomial pneumonia. ${ }^{174}$ They found that the average total costs per episode for linezolid- and vancomycin-treated patients were $€ 12,829$ and $€ 12,409$, respectively, with a similar mean length of stay for both drugs (11.2 vs 10.8 days). They concluded that the use of linezolid was associated with a higher cure rate $(73.6 \%$ vs $64.9 \%$, respectively) and lower death rate (20.7\% vs $33.9 \%)$, at an additional cost of $€ 420$ per treatment episode compared to vancomycin. Patanwala et al carried out a retrospective evaluation of the cost effectiveness of linezolid compared to vancomycin for treating surgical site infections (SSIs) due to MRSA. ${ }^{175}$ Three treatment models were evaluated: treatment with intravenous vancomycin during hospitalization and after discharge with homecare follow-up; treatment with iv vancomycin during hospitalization, followed by oral linezolid after discharge; or treatment with oral linezolid during hospitalization and after discharge. They found that treatment with oral linezolid during hospitalization and after discharge was associated with lower costs $(\$ 8923, \$ 11,479$, and $\$ 12,481$, respectively) and greater effectiveness $(0.867,0.787$, and 0.707 , respectively) compared to the iv vancomycin/oral linezolid switch or iv vancomycin during hospitalization and at home. The costs per MRSA SSI cure were $\$ 10,292$, $\$ 14,486$, and $\$ 17,653$, respectively. They concluded that treatment with oral linezolid during hospitalization and after discharge is expected to be the most cost effective approach for treating SSIs caused by MRSA compared to treatment regimes including iv vancomycin.

\section{Conclusion}

Linezolid has been shown to be active against multiresistant pathogens and to have good efficacy in the treatment of serious Gram-positive infections. Its high oral bioavailability and equivalent intravenous-to-oral formulations lead to ease of dosing and administration, and combined with its good clinical outcomes, make it a cost effective option, allowing early discharge from hospital. There are currently only low resistance rates to 
linezolid, and no cross-resistance with other antimicrobials, associated with its unique mechanism of action, making it a valuable treatment option for multidrug resistant organisms.

The potential problems of treatment with linezolid include its bacteriostatic rather than bacteriocidal action and the relatively high incidence of adverse effects, particularly with long-term use. Long-term use may also be complicated by development of resistance. However, despite its bacteriostatic action, it has been shown to be clinically useful in serious infections where traditionally bacteriocidal agents are required. Several of its adverse effects that occur with prolonged use are reversible and in some clinical situations, the benefits of linezolid treatment may outweigh the potential risks.

Newer oxazolidinones are currently being developed that may have better safety profiles and less resistance than linezolid.

\section{Disclosure}

The authors report no conflicts of interest in this work.

\section{References}

1. Mouton JW, Jansz AR. The DUEL study:a multi-center in vitro evaluation of Linezolid compared with other antibiotics in The Netherlands. Clin Microbiol Infect. 2001;7(9):486-491.

2. Draghi DC, Sheehan DJ, Hogan P, Sahm DF. In vitro activity of linezolid against key gram-positive organisms isolated in the united states: results of the LEADER 2004 surveillance program. Antimicrob Agents Chemother. 2005;49(12):5024-5032.

3. Mutnick AH, Biedenbach DJ, Turnidge JD, Jones RN. Spectrum and potency evaluation of a new oxazolidinone, linezolid: report from the SENTRY Antimicrobial Surveillance Program, 1998-2000. Diagn Microbiol Infect Dis. 2002;43(1):65-73.

4. Jevitt LA, Smith AJ, Williams PP, Raney PM, McGowan JE Jr, Tenover FC. In vitro activities of Daptomycin, Linezolid, and Quinupristin-Dalfopristin against a challenge panel of Staphylococci and Enterococci, including vancomycin-intermediate staphylococcus aureus and vancomycin-resistant Enterococcus faecium. Microb Drug Resist. 2003;9(4):389-393.

5. Fluegge K, Supper S, Siedler A, Berner R. Antibiotic susceptibility in neonatal invasive isolates of Streptococcus agalactiae in a 2-year nationwide surveillance study in Germany. Antimicrob Agents Chemother. 2004;48(11):4444-4446.

6. Jones RN, Stilwell MG, Hogan PA, Sheehan DJ. Activity of linezolid against 3,251 strains of uncommonly isolated gram-positive organisms: report from the SENTRY Antimicrobial Surveillance Program. Antimicrob Agents Chemother. 2007;51(4):1491-1493.

7. Betriu C, Redondo M, Palau ML, et al. Comparative in vitro activities of linezolid, quinupristin-dalfopristin, moxifloxacin, and trovafloxacin against erythromycin-susceptible and -resistant streptococci. Antimicrob Agents Chemother. 2000;44(7):1838-1841.

8. Kosowska-Shick K, Smith K, Bogdanovich T, Ednie LM, Jones RN, Appelbaum PC. Activity of DX-619 compared to other agents against viridans group streptococci, Streptococcus bovis, and Cardiobacterium hominis. Antimicrob Agents Chemother. 2006;50(12):4191-4194.

9. Zhanel GG, Palatnick L, Nichol KA, Bellyou T, Low DE, Hoban DJ. Antimicrobial resistance in respiratory tract Streptococcus pneumoniae isolates: results of the Canadian Respiratory Organism Susceptibility Study, 1997 to 2002. Antimicrob Agents Chemother. 2003;47(6): $1867-1874$.
10. Funke G, Nietznik C. Minimal inhibitory concentrations of linezolid against clinical isolates of coryneform bacteria. Eur J Clin Microbiol Infect Dis. 2005;24(9):612-614.

11. Klare I, Konstabel C, Werner G, et al. Antimicrobial susceptibilities of Lactobacillus, Pediococcus and Lactococcus human isolates and cultures intended for probiotic or nutritional use. $J$ Antimicrob Chemother. 2007;59(5):900-912.

12. Bowersock TL, Salmon SA, Portis ES, et al. MICs of oxazolidinones for Rhodococcus equi strains isolated from humans and animals. Antimicrob Agents Chemother. 2000;44(5):1367-1369.

13. Brown-Elliott BA, Ward SC, Crist CJ, Mann LB, Wilson RW, Wallace RJ Jr. In vitro activities of linezolid against multiple Nocardia species. Antimicrob Agents Chemother. 2001;45(4):1295-1297.

14. Ackermann G, Adler D, Rodloff AC. In vitro activity of linezolid against Clostridium difficile. J Antimicrob Chemother. 2003;51(3):743-745.

15. Baines SD, Noel AR, Huscroft GS, et al. Evaluation of linezolid for the treatment of Clostridium difficile infection caused by epidemic strains using an in vitro human gut model. J Antimicrob Chemother. 2011;66(7):1537-1546.

16. Daeschlein G, Hoehne C, Assadian O, et al. In vitro activity of linezolid against clinical isolates of Fusobacterium spp. JAntimicrob Chemother. 2006;58(4):789-793.

17. Citron DM, Merriam CV, Tyrrell KL, Warren YA, Fernandez H, Goldstein EJ. In vitro activities of ramoplanin, teicoplanin, vancomycin, linezolid, bacitracin, and four other antimicrobials against intestinal anaerobic bacteria. Antimicrob Agents Chemother. 2003; 47(7):2334-2338.

18. Molitoris D, Väisänen ML, Bolaños M, Finegold SM. In vitro activities of DX-619 and four comparator agents against 376 anaerobic bacterial isolates. Antimicrob Agents Chemother. 2006;50(5):1887-1889.

19. Smith AJ, Hall V, Thakker B, Gemmell CG. Antimicrobial susceptibility testing of Actinomyces species with 12 antimicrobial agents. $J$ Antimicrob Chemother. 2005;56(2):407-409.

20. Brown-Elliott BA, Crist CJ, Mann LB, Wilson RW, Wallace RJ Jr. In vitro activity of linezolid against slowly growing nontuberculous Mycobacteria. Antimicrob Agents Chemother. 2003;47(5): $1736-1738$.

21. Yang SC, Hsueh PR, Lai HC, et al. High prevalence of antimicrobial resistance in rapidly growing mycobacteria in Taiwan. Antimicrob Agents Chemother. 2003;47(6):1958-1962.

22. Shinabarger D. Mechanism of action of the oxazolidinone antibacterial agents. Expert Opin Investig Drugs. 1999;8(8):1195-1202.

23. Colca JR, McDonald WG, Waldon DJ, et al. Crosslinking in the living cell locates the site of action of oxazolidinone antibiotics. J Biol Chem. 2003;278(24):21972-21979.

24. Leach KL, Swaney SM, Colca JR, et al. The site of action of oxazolidinone antibiotics in living bacteria and in human mitochondria. Mol Cell. 2007;26(3):393-402.

25. Jones RN, Kohno S, Ono Y, Ross JE, Yanagihara K. ZAAPS International Surveillance Program (2007) for linezolid resistance: results from 5591 Gram-positive clinical isolates in 23 countries. Diagn Microbiol Infect Dis. 2009;64(2):191-201.

26. Farrell DJ, Mendes RE, Ross JE, Jones RN. Linezolid surveillance program results for 2008 (LEADER Program for 2008). Diagn Microbiol Infect Dis. 2009;65(4):392-403.

27. Ross JE, Farrell DJ, Mendes RE, Sader HS, Jones RN. Eight-year (2002-2009) summary of the linezolid (Zyvox ${ }^{\circledR}$ Annual Appraisal of Potency and Spectrum; ZAAPS) program in European countries. J Chemother. 2011;23(2):71-76.

28. Zurenko G, Todd WM, Hafkin BA. Development of linezolid-resistant Enterococcus faecium in two compassionate use program patients treated with linezolid (abstract). Proceedings of the 39th Annual Interscience Conference on Antimicrobial Agents and Chemotherapy (ICAAC); San Francisco, CA. September 26-29, 1999.

29. Gonzales RD, Schreckenberger PC, Graham MB, Kelkar S, DenBesten K, Quinn JP. Infections due to vancomycin-resistant Enterococcus faecium resistant to linezolid. Lancet. 2001;357(9263):1179. 
30. Tsiodras S, Gold HS, Sakoulas G, et al. Linezolid resistance in a clinical isolate of Staphylococcus aureus. Lancet. 2001;358(9277):207-208.

31. Potoski BA, Adams J, Clarke L, et al. Epidemiological profile of linezolid-resistant coagulase-negative staphylococci. Clin Infect Dis. 2006;43(2):165-171.

32. Jones RN, Fritsche TR, Sader HS, Ross JE. Zyvox Annual Appraisal of Potency and Spectrum Program Results for 2006: an activity and spectrum analysis of linezolid using clinical isolates from 16 countries. Diagn Microbiol Infect Dis. 2007;59(2):199-209.

33. Mutnick AH, Enne V, Jones RN. Linezolid resistance since 2001: SENTRY Antimicrobial Surveillance Program. Ann Pharmacother 2003;37(6):769-774.

34. Meka VG, Gold HS. Antimicrobial resistance to linezolid. Clin Infect Dis. 2004;39(7):1010-1015.

35. Kelly S, Collins J, Maguire M, et al. An outbreak of colonization with linezolid-resistant Staphylococcus epidermidis in an intensive therapy unit. J Antimicrob Chemother. 2008;61(4):901-907.

36. Prystowsky J, Siddiqui F, Chosay J, et al. Resistance to linezolid: characterization of mutations in rRNA and comparison of their occurrences in vancomycin-resistant enterococci. Antimicrob Agents Chemother. 2001;45(7):2154-2156.

37. Farrell DJ, Mendes RE, Ross JE, Sader HS, Jones RN. LEADER Program results for 2009: an activity and spectrum analysis of linezolid using 6,414 clinical isolates from 56 medical centers in the United States. Antimicrob Agents Chemother. 2011;55(8):3684-3690.

38. Kola A, Kirschner P, Gohrbandt B, et al. An infection with linezolidresistant $\mathrm{S}$. aureus in a patient with left ventricular assist system. Scand $J$ Infect Dis. 2007;39(5):463-465.

39. Dobbs TE, Patel M, Waites KB, Moser SA, Stamm AM, Hoesley CJ. Nosocomial spread of Enterococcus faecium resistant to vancomycin and linezolid in a tertiary care medical center. J Clin Microbiol. 2006;44(9):3368-3370.

40. Miller K, O’Neill AJ, Wilcox MH, Ingham E, Chopra I. Delayed development of linezolid resistance in Staphylococcus aureus following exposure to low levels of antimicrobial agents. Antimicrob Agents Chemother. 2008;52(6):1940-1944.

41. Kehrenberg C, Schwarz S, Jacobsen L, Hansen LH, Vester B. A new mechanism for chloramphenicol, florfenicol and clindamycin resistance: methylation of 23S ribosomal RNA at A2503. Mol Microbiol. 2005;57(4):1064-1073.

42. Toh SM, Xiong L, Arias CA, et al. Acquisition of a natural resistance gene renders a clinical strain of methicillin-resistant Staphylococcus aureus resistant to the synthetic antibiotic linezolid. Mol Microbiol. 2007;64(6):1506-1514.

43. Welshman IR, Sisson TA, Jungbluth GL, Stalker DJ, Hopkins NK. Linezolid absolute bioavailability and the effect of food on oral bioavailability. Biopharm Drug Dispos. 2001;22(3):91-97.

44. Gee T, Ellis R, Marshall G, Andrews J, Ashby J, Wise R. Pharmacokinetics and tissue penetration of linezolid following multiple oral doses. Antimicrob Agents Chemother. 2001;45(6):1843-1846.

45. Slatter JG, Stalker DJ, Feenstra KL, et al. Pharmacokinetics, metabolism, and excretion of linezolid following an oral dose of $[(14) \mathrm{C}]$ linezolid to healthy human subjects. Drug Metab Dispos. 2001;29(8):1136-1145.

46. Stalker DJ, Jungbluth GL. Clinical pharmacokinetics of linezolid, a novel oxazolidinone antibacterial. Clin Pharmacokinet. 2003; 42(13):1129-1140.

47. Grunder G, Zysset-Aschmann Y, Vollenweider F, Maier T, Krähenbühl S, Drewe J. Lack of pharmacokinetic interaction between linezolid and antacid in healthy volunteers. Antimicrob Agents Chemother. 2006;50(1):68-72.

48. Keel RA, Schaeftlein A, Kloft C, et al. Pharmacokinetics of intravenous and oral linezolid in adults with cystic fibrosis. Antimicrob Agents Chemother. 2011;55(7):3393-3398.

49. Stalker DJ, Jungbluth GL, Hopkins NK, Batts DH. Pharmacokinetics and tolerance of single- and multiple-dose oral or intravenous linezolid, an oxazolidinone antibiotic in healthy volunteers. J Antimicrob Chemother. 2003;51(5):1239-1246.
50. MacGowan AP. Pharmacokinetic and pharmacodynamic profile of linezolid in healthy volunteers and patients with Gram-positive infections. J Antimicrob Chemother. 2003;51 Suppl 2:ii17-25.

51. Meagher AK, Forrest A, Rayner CR, Birmingham MC, Schentag JJ. Population pharmacokinetics of linezolid in patients treated in a compassionate-use program. Antimicrob Agents Chemother. 2003;47(2):548-553.

52. Adembri C, Fallani S, Cassetta MI, et al. Linezolid pharmacokinetic/pharmacodynamic profile in critically ill septic patients: intermittent versus continuous infusion. Int $J$ Antimicrob Agents. 2008;31(2):122-129.

53. Sisson TL, Jungbluth GL, Hopkins NK. Age and sex effects on the pharmacokinetics of linezolid. Eur J Clin Pharmacol. 2002;57(11):793-797.

54. Clemett D, Markham A. Linezolid. Drugs. 2000;59(4):815-827.

55. Dehghanyar P, Bürger C, Zeitlinger M, et al. Penetration of linezolid into soft tissues of healthy volunteers after single and multiple doses. Antimicrob Agents Chemother. 2005;49(6):2367-2371.

56. Lovering AM, Zhang J, Bannister GC, et al. Penetration of linezolid into bone, fat, muscle and haematoma of patients undergoing routine hip replacement. J Antimicrob Chemother. 2002;50:73-77.

57. Kutscha-Lissberg F, Hebler U, Muhr G, Köller M. Linezolid penetration into bone and joint tissues infected with methicillinresistant staphylococci. Antimicrob Agents Chemother. 2003;47(12): 3964-3966.

58. Boselli E, Breilh D, Rimmelé T, et al. Pharmacokinetics and intrapulmonary concentrations of linezolid administered to critically ill patients with ventilator-associated pneumonia. Crit Care Med. 2005;33(7):1529-1533.

59. Honeybourne D, Tobin C, Jevons G, Andrews J, Wise R. Intrapulmonary penetration of linezolid. Antimicrob Chemother. 2003;51(6): $1431-1434$

60. Conte JE Jr, Golden JA, Kipps J, Zurlinden E. Intrapulmonary pharmacokinetics of linezolid. Antimicrob Agents Chemother. 2002;46(5):1475-1480.

61. Tsona A, Metallidis S, Foroglou N, et al. Linezolid penetration into cerebrospinal fluid and brain tissue. J Chemother. 2010;22(1): 17-19.

62. Boak LM, Li J, Spelman D, du Cros P, Nation RL, Rayner CR. Successful treatment and cerebrospinal fluid penetration of oral linezolid in a patient with coagulase-negative Staphylococcus ventriculitis. Ann Pharmacother. 2006;40(7-8):1451-1455.

63. Myrianthefs P, Markantonis SL, Vlachos K, et al. Serum and Cerebrospinal Fluid Concentrations of Linezolid in Neurosurgical Patients. Antimicrob Agents Chemother. 2006;50(12):3971-3976.

64. Beer R, Engelhardt KW, Pfausler B, et al. Pharmacokinetics of intravenous linezolid in cerebrospinal fluid and plasma in neurointensive care patients with staphylococcal ventriculitis associated with external ventricular drains. Antimicrob Agents Chemother. 2007;51:379-382.

65. Viaggi B, Paolo AD, Danesi R, et al. Linezolid in the central nervous system: comparison between cerebrospinal fluid and plasma pharmacokinetics. Scand J Infect Dis. 2011;43(9):721-727.

66. Prydal JI, Jenkins DR, Lovering A, Watts A. The pharmacokinetics of linezolid in the non-inflamed human eye. Br J Ophthalmol. 2005;89(11):1418-1419.

67. Vázquez EG, Mensa J, López Y, et al. Penetration of linezolid into the anterior chamber (aqueous humor) of the human eye after intravenous administration. Antimicrob Agents Chemother. 2004;48(2): 670-672.

68. Buerger C, Plock N, Dehghanyar P, Joukhadar C, Kloft C.Pharmacokinetics of unbound linezolid in plasma and tissue interstitium of critically ill patients after multiple dosing using microdialysis. Antimicrob Agents Chemother. 2006;50(7):2455-2463.

69. Rao GG, Steger A, Tobin CM. linezolid levels in pancreatic secretions. J Antimicrob Chemother. 2001; 48(6):931-932.

70. DePestel DD, Peloquin CA, Carver PL. Peritoneal dialysis fluid concentrations of linezolid in the treatment of vancomycin-resistant Enterococcus faecium peritonitis. Pharmacotherapy. 2003;23(10):1322-1326. 
71. Dehghanyar P, Bürger C, Zeitlinger M, et al. Penetration of linezolid into soft tissues of healthy volunteers after single and multiple doses. Antimicrob Agents Chemother. 2005;49(6):2367-2371.

72. Sagirli O, Onal A, Toker S, Oztunç A. Determination of linezolid in human breast milk by high-performance liquid chromatography with ultraviolet detection. J AOAC Int. 2009;92(6):1658-1662.

73. Wilcox MH, Kite P, Mills K, Sugden S. In situ measurement of linezolid and vancomycin concentrations in intravascular catheter-associated biofilm. J Antimicrob Chemother. 2001;47(2):171-175.

74. Wiederhold NP, Coyle EA, Raad II, Prince RA, Lewis RE. Antibacterial activity of linezolid and vancomycin in an in vitro pharmacodynamic model of Gram-positive catheter-related bacteraemia. J Antimicrob Chemother. 2005;55(5):792-795.

75. Bayston R, Nuradeen B, Ashraf W, Freeman BJ. Antibiotics for the eradication of Propionibacterium acnes biofilms in surgical infection. J Antimicrob Chemother. 2007;60(6):1298-1301.

76. Leite B, Gomes F, Teixeira P, Souza C, Pizzolitto E, Oliveira R. In vitro activity of daptomycin, linezolid and rifampicin on Staphylococcus epidermidis biofilms. Curr Microbiol. 2011;63(3):313-317.

77. Bayston R, Ullas G, Ashraf W. The action of linezolid or vancomycin on biofilms in ventriculoperitoneal shunts in vitro. Antimicrob Agents Chemother. 2012. [Epub ahead of print.]

78. Holmberg A, Mörgelin M, Rasmussen M. Effectiveness of ciprofloxacin or linezolid in combination with rifampicin against Enterococcus faecalis in biofilms. J Antimicrob Chemother. 2012;67(2):433-439.

79. Sandoe JA, Wysome J, West AP, Heritage J, Wilcox MH. Measurement of ampicillin, vancomycin, linezolid and gentamicin activity against enterococcal biofilms. J Antimicrob Chemother. 2006;57(4): 767-770.

80. Brier ME, Stalker DJ, Aronoff GR, et al. Pharmacokinetics of linezolid in subjects with renal dysfunction. Antimicrob Agents Chemother. 2003;47(9):2775-2780.

81. Hendershot PE, Jungbluth GL, Cammarata SK, Hopkins NJ. Pharmacokinetics of linezolid in patients with liver disease. JAntimicrob Chemother. 1999;44(Suppl A):55.

82. Fiaccadori E, Maggiore U, Rotelli C, et al. Removal of linezolid by conventional intermittent hemodialysis, sustained low-efficiency dialysis, or continuous venovenous hemofiltration in patients with acute renal failure. Crit Care Med. 2004;32(12):2437-2442.

83. Meyer B, Kornek GV, Nikfardjam M, et al. Multiple-dose pharmacokinetics of linezolid during continuous venovenous haemofiltration. J Antimicrob Chemother. 2005;56(1):172-179.

84. Trotman RL, Williamson JC, Shoemaker DM, Salzer WL. Antibiotic dosing in critically ill adult patients receiving continuous renal replacement therapy. Clin Infect Dis. 2005;41(8):1159-1166.

85. Kearns GL, Abdel-Rahman SM, Blumer JL, et al. Single dose pharmacokinetics of linezolid in infants and children. Pediatr Infect Dis J. 2000;19(12):1178-1184.

86. Wise R, Andrews JM, Boswell FJ, Ashby JP. The in-vitro activity of linezolid (U-100766) and tentative breakpoints. J Antimicrob Chemother. 1998;42(6):721-728.

87. Bowker KE, Wootton M, Holt HA, MacGowan AP. In vitro activity of linezolid against Gram-positive isolates causing infection in continuous ambulatory peritoneal dialysis patients. J Antimicrob Chemother. 2002;49(3):578-580.

88. Zurenko GE, Yagi BH, Schaadt RD, et al. In vitro activities of U-100592 and U-100766, novel oxazolidinone antibacterial agents. Antimicrob Agents Chemother. 1996;40(4):839-845.

89. Rybak MJ, Cappelletty DM, Moldovan T, Aeschlimann JR, Kaatz GW. Comparative in vitro activities and postantibiotic effects of the oxazolidinone compounds eperezolid (PNU-100592) and linezolid (PNU-100766) versus vancomycin against Staphylococcus aureus, coagulase-negative staphylococci, Enterococcus faecalis, and Enterococcus faecium. Antimicrob Agents Chemother. 1998;42(3): 721-724.

90. Wilcox M, Nathwani D, Dryden M. Linezolid compared with teicoplanin for the treatment of suspected or proven Gram-positive infections. J Antimicrob Chemother. 2004;53(2):335-344.
91. Wilcox MH, Tack KJ, Bouza E, et al. Complicated skin and skinstructure infections and catheter-related bloodstream infections: noninferiority of linezolid in a phase 3 study. Clin Infect Dis. 2009; 48(2):203-212.

92. Falagas ME, Siempos II, Vardakas KZ. Linezolid versus glycopeptide or beta-lactam for treatment of Gram-positive bacterial infections: meta-analysis of randomised controlled trials. Lancet Infect Dis. 2008;8(1):53-66.

93. Beibei L, Yun C, Mengli C, Nan B, Xuhong Y, Rui W. Linezolid versus vancomycin for the treatment of gram-positive bacterial infections: meta-analysis of randomised controlled trials. Int J Antimicrob Agents. 2010;35(1):3-12.

94. Jang HC, Kim SH, Kim KH, et al. Salvage treatment for persistent methicillin-resistant Staphylococcus aureus bacteremia: efficacy of linezolid with or without carbapenem. Clin Infect Dis. 2009;49(3): 395-401.

95. Jauregui LE, Babazadeh S, Seltzer E, et al. Randomized, double-blind comparison of once-weekly dalbavancin versus twice-daily linezolid therapy for the treatment of complicated skin and skin structure infections. Clin Infect Dis. 2005;41(10):1407-1415.

96. Weigelt J, Itani K, Stevens D, Lau W, Dryden M, Knirsch C; Linezolid CSSTI Study Group. Linezolid versus vancomycin in treatment of complicated skin and soft tissue infections. Antimicrob Agents Chemother. 2005;49(6):2260-2266.

97. Stevens DL, Smith LG, Bruss JB, et al. Randomized comparison of linezolid (PNU-100766) versus oxacillin-dicloxacillin for treatment of complicated skin and soft tissue infections. Antimicrob Agents Chemother. 2000;44(12):3408-3413.

98. Bounthavong M, Hsu DI. Efficacy and safety of linezolid in methicillin-resistant Staphylococcus aureus (MRSA) complicated skin and soft tissue infection (cSSTI): a meta-analysis. Curr Med Res Opin. 2010;26(2):407-421.

99. Saroglou M, Tryfon S, Ismailos G, et al. Pharmacokinetics of Linezolid and Ertapenem in experimental parapneumonic pleural effusion. J Inflamm (Lond). 2010;7:22.

100. San Pedro GS, Cammarata SK, Oliphant TH, Todisco T; Linezolid Community-Acquired Pneumonia Study Group. Linezolid versus ceftriaxone/cefpodoxime in patients hospitalized for the treatment of Streptococcus pneumoniae pneumonia. Scand J Infect Dis. 2002;34(10):720-728.

101. Walkey AJ, O’Donnell MR, Wiener RS. Linezolid versus glycopeptide antibiotics for the treatment of suspected methicillin-resistant Staphylococcus aureus nosocomial pneumonia: a meta-analysis of randomized controlled trials. Chest. 2011;139(5):1148-1155.

102. Wunderink RG, Niederman MS, Kollef MH, et al. Linezolid in methicillin-resistant Staphylococcus aureus nosocomial pneumonia: a randomized, controlled study. Clin Infect Dis. 2012;54(5): 621-629.

103. Rana B, Butcher I, Grigoris P, Murnaghan C, Seaton RA, Tobin CM. Linezolid penetration into osteo-articular tissues. J Antimicrob Chemother. 2002;50(5):747-750.

104. Howden BP, Ward PB, Charles PG, et al. Treatment outcomes for serious infections caused by methicillin-resistant Staphylococcus aureus with reduced vancomycin susceptibility. Clin Infect Dis. 2004;38(4):521-528.

105. Aneziokoro CO, Cannon JP, Pachucki CT, Lentino JR. The effectiveness and safety of oral linezolid for the primary and secondary treatment of osteomyelitis. J Chemother. 2005;17(6):643-650.

106. Rayner CR, Baddour LM, Birmingham MC, Norden C, Meagher AK, Schentag JJ. Linezolid in the treatment of osteomyelitis: results of compassionate use experience. Infection. 2004;32(1):8-14.

107. Dailey CF, Dileto-Fang CL, Buchanan LV, et al. Efficacy of linezolid in treatment of experimental endocarditis caused by methicillinresistant Staphylococcus aureus. Antimicrob Agents Chemother. 2001;45(8):2304-2308.

108. Patel R, Rouse MS, Piper KE, Steckelberg JM. Linezolid therapy of vancomycin-resistant Enterococcus faecium experimental endocarditis. Antimicrob Agents Chemother. 2001;45(2):621-623. 
109. Muñoz P, Rodríguez-Creixéms M, Moreno M, Marín M, Ramallo V, Bouza E; GAME Study Group. Linezolid therapy for infective endocarditis. Clin Microbiol Infect. 2007;13(2):211-215.

110. Tsigrelis C, Singh KV, Coutinho TD, Murray BE, Baddour LM. Vancomycin-resistant Enterococcus faecalis endocarditis: linezolid failure and strain characterization of virulence factors. $J$ Clin Microbiol. 2007;45(2):631-635.

111. Corne P, Marchandin H, Macia JC, Jonquet O. Treatment failure of methicillin-resistant Staphylococcus aureus endocarditis with linezolid. Scand J Infect Dis. 2005;37(11-12):946-949.

112. Falagas ME, Manta KG, Ntziora F, Vardakas KZ. Linezolid for the treatment of patients with endocarditis: a systematic review of the published evidence. J Antimicrob Chemother. 2006;58(2): 273-280.

113. Jacqueline C, Asseray N, Batard E, et al. In vivo efficacy of linezolid in combination with gentamicin for the treatment of experimental endocarditis due to methicillin-resistant Staphylococcus aureus. Int J Antimicrob Agents. 2004;24(4):393-396.

114. Nagashima G, Okamoto N, Okuda M, et al. Effect of linezolid against postneurosurgical meningitis caused by methicillin-resistant Staphylococcus epidermidis: case report. J Infect Chemother. 2008;14(2):147-150.

115. Krueger WA, Kottler B, Will BE, Heininger A, Guggenberger H, Unertl KE. Treatment of meningitis due to methicillin-resistant Staphylococcus epidermidis with linezolid. J Clin Microbiol. 2004;42(2):929-932.

116. Castro P, Soriano A, Escrich C, Villalba G, Sarasa M, Mensa J. Linezolid treatment of ventriculoperitoneal shunt infection without implant removal. Eur J Clin Microbiol Infect Dis. 2005;24(9):603-606.

117. Tsuji Y, Hiraki Y, Matsumoto K, et al. Pharmacokinetics and protein binding of linezolid in cerebrospinal fluid and serum in a case of post-neurosurgical bacterial meningitis. Scand J Infect Dis 2011;43(11-12):982-985.

118. Zeana C, Kubin CJ, Della-Latta P, Hammer SM. Vancomycin-resistant Enterococcus faecium meningitis successfully managed with linezolid: case report and review of the literature. Clin Infect Dis. 2001;33(4):477-482.

119. Faella F, Pagliano P, Fusco U, Attanasio V, Conte M. Combined treatment with ceftriaxone and linezolid of pneumococcal meningitis: a case series including penicillin-resistant strains. Clin Microbiol Infect. 2006;12(4):391-394.

120. Ramírez P, Sahuquillo JM, Cortés C, Kot P, Bonastre JM. Linezolid as rescue therapy for pneumococcal meningitis. Intensive Care Med. 2007;33(5):924-925.

121. Leiti O, Gross JW, Tuazon CU. Treatment of brain abscess caused by Listeria monocytogenes in a patient with allergy to penicillin and trimethoprim-sulfamethoxazole. Clin Infect Dis. 2005; 40(6):907-908.

122. Viganò SM, Edefonti A, Ferraresso M, et al. Successful medical treatment of multiple brain abscesses due to Nocardia farcinica in a paediatric renal transplant recipient. Pediatr Nephrol. 2005;20(8): 1186-1188.

123. Jaksic B, Martinelli G, Perez-Oteyza J, Hartman CS, Leonard LB, Tack KJ. Efficacy and safety of linezolid compared with vancomycin in a randomized, double-blind study of febrile neutropenic patients with cancer. Clin Infect Dis. 2006;42(5):597-607.

124. Nannini EC, Keating M, Binstock P, Samonis G, Kontoyiannis DP. Successful treatment of refractory disseminated Mycobacterium avium complex infection with the addition of linezolid and mefloquine. $J$ Infect. 2002;44(3):201-203.

125. Kyle SD, Porter WM. Mycobacterium chelonae infection successfully treated with oral clarithromycin and linezolid. Br J Dermatol. 2004; 151(5):1101.

126. Ntziora F, Falagas ME. Linezolid for the treatment of patients with mycobacterial infections a systematic review. Int J Tuberc Lung Dis. 2007;11(6):606-611.

127. Rubinstein E, Cammarata S, Oliphant T, Wunderink R; Linezolid Nosocomial Pneumonia Study Group. Linezolid (PNU-100766) versus vancomycin in the treatment of hospitalized patients with nosocomial pneumonia: a randomized, double-blind, multicenter study. Clin Infect Dis. 2001;32(3):402-412.
128. Stevens DL, Herr D, Lampiris H, Hunt JL, Batts DH, Hafkin B. Linezolid versus vancomycin for the treatment of methicillin-resistant Staphylococcus aureus infections. Clin Infect Dis. 2002;34(11): 1481-1490.

129. Rubinstein E, Isturiz R, Standiford HC, et al. Worldwide assessment of linezolid's clinical safety and tolerability: comparator-controlled phase III studies. Antimicrob Agents Chemother. 2003;47(6):1824-1831.

130. Kaplan SL, Deville JG, Yogev R, et al. Linezolid versus vancomycin for treatment of resistant Gram-positive infections in children. Pediatr Infect Dis J. 2003;22(8):677-686.

131. Falagas ME, Vardakas KZ. Benefit-risk assessment of linezolid for serious gram-positive bacterial infections. Drug Saf. 2008;31(9): 753-768.

132. Cawley MJ, Lipka O. Intravenous linezolid administered orally: a novel desensitization strategy. Pharmacotherapy. 2006;26(4):563-568.

133. Bishop E, Melvani S, Howden BP, Charles PG, Grayson ML. Good clinical outcomes but high rates of adverse reactions during linezolid therapy for serious infections: a proposed protocol for monitoring therapy in complex patients. Antimicrob Agents Chemother. 2006; 50(4):1599-1602.

134. Kelley W, Resh B, Goldenberg G., Linezolid-induced purpuric medication reaction. J Cutan Pathol. 2009;36(7):793-795.

135. Esposito L, Kamar N, Guilbeau-Frugier C, Mehrenberger M, Modesto A, Rostaing L. Linezolid-induced interstitial nephritis in a kidney-transplant patient. Clin Nephrol. 2007;68(5):327-329.

136. Savard S, Desmeules S, Riopel J, Agharazii M. Linezolid-associated acute interstitial nephritis and drug rash with eosinophilia and systemic symptoms (DRESS) syndrome. Am J Kidney Dis. 2009; 54(6):e17-e20.

137. Apodaca AA, Rakita RM. Linezolid-induced lactic acidosis. $N$ Engl J Med. 2003;348:86-87.

138. Su E, Crowley K, Carcillo JA, Michaels MG. Linezolid and lactic acidosis: a role for lactate monitoring with long-term linezolid use in children. Pediatr Infect Dis J. 2011;30(9):804-806.

139. Scotton P, Fuser R, Torresan S, et al. Early linezolid-associated lactic acidosis in a patient treated for tuberculous spondylodiscitis. Infection . 2008;36(4):387-388

140. Contou D, Fichet J, Grimaldi D, Cariou A. Early life-threatening lactic acidosis following a single infusion of linezolid. Int $J$ Antimicrob Agents. 2011;38(1):84-85.

141. Palenzuela L, Hahn NM, Nelson RP Jr, et al. Does linezolid cause lactic acidosis by inhibiting mitochondrial protein synthesis? Clin Infect Dis. 2005;40(12):e113-e116.

142. Garrabou G, Soriano A, López S, et al. Reversible inhibition of mitochondrial protein synthesis during linezolid-related hyperlactatemia. Antimicrob Agents Chemother. 2007;51(3):962-967.

143. Carson J, Cerda J, Chae JH, Hirano M, Maggiore P. Severe lactic acidosis associated with linezolid use in a patient with the mitochondrial DNA A2706G polymorphism. Pharmacotherapy. 2007; 27(5): 771-774.

144. French G. Safety and tolerability of linezolid. J Antimicrob Chemother. 2003;51 Suppl 2:ii45-53.

145. Monson T, Schichman SA, Zent CS. Linezolid-induced pure red blood cell aplasia. Clin Infect Dis. 2002;35(3):E29-E31.

146. Attassi K, Hershberger E, Alam R, Zervos MJ. Thrombocytopenia associated with linezolid therapy. Clin Infect Dis. 2002;34(5): 695-698.

147. Gerson SL, Kaplan SL, Bruss JB. Hematologic effects of linezolid: summary of clinical experience. Antimicrob Agents Chemother. 2002;46(8):2723-2726.

148. Nasraway SA, Shorr AF, Kuter DJ, O’Grady N, Le VH, Cammarata SK. Linezolid does not increase the risk of thrombocytopenia in patients with nosocomial pneumonia: comparative analysis of linezolid and vancomycin use. Clin Infect Dis. 2003;37(12):1609-1616.

149. Weigelt J, Itani K, Stevens D, Lau W, Dryden M, Knirsch C; Linezolid CSSTI Study Group. Linezolid versus vancomycin in treatment of complicated skin and soft tissue infections. Antimicrob Agents Chemother. 2005;49(6):2260-2266.

150. Bernstein WB, Trotta RF, Rector JT, Tjaden JA, Barile AJ. Mechanisms for linezolid-induced anemia and thrombocytopenia. Ann Pharmacother. 2003;37(4):517-520. 
151. Orrick JJ, Johns T, Janelle J, Ramphal R. Thrombocytopenia secondary to linezolid administration: what is the risk? Clin Infect Dis. 2002;35(3):348-349.

152. Birmingham MC, Rayner CR, Meagher AK, Flavin SM, Batts DH, Schentag JJ. Linezolid for the treatment of multidrug-resistant, grampositive infections: experience from a compassionate-use program. Clin Infect Dis. 2003;36(2):159-168.

153. Kuter DJ, Tillotson GS. Hematologic effects of antimicrobials: focus on the oxazolidinone linezolid. Pharmacotherapy. 2001;8:1010-1013.

154. Lin YH, Wu VC, Tsai IJ. High frequency of linezolid-associated thrombocytopenia among patients with renal insufficiency. Int J Antimicrob Agents. 2006;28(4):345-351.

155. Hiraki Y, Tsuji Y, Matsumoto K, Morita K, Kamimura H, Karube Y. Influence of linezolid clearance on the induction of thrombocytopenia and reduction of hemoglobin. Am J Med Sci. 2011;342(6):456-460.

156. Tsuji Y, Hiraki Y, Matsumoto K, et al. Thrombocytopenia and anemia caused by a persistent high linezolid concentration in patients with renal dysfunction. J Infect Chemother. 2011;17(1):70-75.

157. Cohen N, Mihu CN, Seo SK, et al. Hematologic safety profile of linezolid in the early periengraftment period after allogeneic stem cell transplantation. Biol Blood Marrow Transplant. 2009;15(10): 1337-1341.

158. De Bus L, Depuydt P, Libbrecht L, et al. Severe drug-induced liver injury associated with prolonged use of linezolid. $J$ Med Toxicol. 2010;6(3):322-326.

159. Bressler AM, Zimmer SM, Gilmore JL, Somani J. Peripheral neuropathy associated with prolonged use of linezolid. Lancet Infect Dis. 2004;4(8):528-531.

160. Legout L, Senneville E, Gomel JJ, Yazdanpanah Y, Mouton Y. Linezolid-induced neuropathy. Clin Infect Dis. 2004;38(5): 767-768.

161. Rucker JC, Hamilton SR, Bardenstein D, Isada CM, Lee MS. Linezolid-associated toxic optic neuropathy. Neurology. 2006;66(4): 595-598

162. Javaheri M, Khurana RN, O’hearn TM, Lai MM, Sadun AA. Linezolidinduced optic neuropathy: a mitochondrial disorder? Br J Ophthalmol. 2007;91(1):111-115.

163. Joshi L, Taylor SR, Large O, Yacoub S, Lightman S. A case of optic neuropathy after short-term linezolid use in a patient with acute lymphocytic leukemia. Clin Infect Dis. 2009;48(7):e73-e74.

164. Thai XC, Bruno-Murtha LA. Bell's palsy associated with linezolid therapy: case report and review of neuropathic adverse events. Pharmacotherapy. 2006;26(8):1183-1189.
165. Wynalda MA, Hauer MJ, Wienkers LC. Oxidation of the novel oxazolidinone antibiotic linezolid in human liver microsomes. Drug Metab Dispos. 2000;28(9):1014-1017.

166. Hendershot PE, Antal EJ, Welshman IR, Batts DH, Hopkins NK. Linezolid: pharmacokinetic and pharmacodynamic evaluation of coadministration with pseudoephedrine $\mathrm{HCl}$, phenylpropanolamine $\mathrm{HCl}$, and dextromethorpan HBr. J Clin Pharmacol. 2001;41(5): 563-572.

167. Wigen CL, Goetz MB. Serotonin syndrome and linezolid. Clin Infect Dis. 2002;34(12):1651-1652.

168. Bergeron L, Boulé M, Perreault S. Serotonin toxicity associated with concomitant use of linezolid. Ann Pharmacother. 2005;39(5): 956-961.

169. Huang V, Gortney JS. Risk of serotonin syndrome with concomitant administration of linezolid and serotonin agonists. Pharmacotherapy. 2006;26(12):1784-1793.

170. Butterfield JM, Lawrence KR, Reisman A, Huang DB, Thompson CA, Lodise TP. Comparison of serotonin toxicity with concomitant use of either linezolid or comparators and serotonergic agents: an analysis of Phase III and IV randomized clinical trial data. J Antimicrob Chemother. 2012;67(2):494-502.

171. Lawrence KR, Adra M, Gillman PK. Serotonin toxicity associated with the use of linezolid: a review of postmarketing data. Clin Infect Dis. 2006;42(11):1578-1583.

172. Bounthavong M, ZargarzadehA, Hsu DI, Vanness DJ. Cost-effectiveness analysis of linezolid, daptomycin, and vancomycin in methicillinresistant Staphylococcus aureus: complicated skin and skin structure infection using Bayesian methods for evidence synthesis. Value Health. 2011;14(5):631-639.

173. Schürmann D, Sorensen SV, De Cock E, Duttagupta S, Resch A. Costeffectiveness of linezolid versus vancomycin for hospitalised patients with complicated skin and soft-tissue infections in Germany. Eur J Health Econ. 2009;10(1):65-79.

174. De Cock E, Krueger WA, Sorensen S, et al. Cost-effectiveness of linezolid vs vancomycin in suspected methicillin-resistant Staphylococcus aureus nosocomial pneumonia in Germany. Infection. 2009;37(2):123-132.

175. Patanwala AE, Erstad BL, Nix DE. Cost-effectiveness of linezolid and vancomycin in the treatment of surgical site infections. Curr Med Res Opin. 2007;23(1):185-193.
Infection and Drug Resistance

\section{Publish your work in this journal}

Infection and Drug Resistance is an international, peer-reviewed openaccess journal that focuses on the optimal treatment of infection (bacterial, fungal and viral) and the development and institution of preventive strategies to minimize the development and spread of resistance. The journal is specifically concerned with the epidemiology of antibiotic

\section{Dovepress}

resistance and the mechanisms of resistance development and diffusion in both hospitals and the community. The manuscript management system is completely online and includes a very quick and fair peerreview system, which is all easy to use. Visit http://www.dovepress.com/ testimonials.php to read real quotes from published authors. 